\title{
Human Herpesvirus-8 and Other Viral Infections, Papua New Guinea
}

\author{
Giovanni Rezza,* Robert T. Danaya, $†$ Theresa M. Wagner,* Loredana Sarmati,‡ \\ Ifor L. Owen,§ Paolo Monini,* Massimo Andreoni,‡ Barbara Suligoi,* \\ Barbara E nsoli,* and E doardo Pozio* \\ *I stituto Superiore di Sanità, Rome, Italy; †Port Moresby General Hospital, Port Moresby, Papua New \\ Guinea; ¥Tor Vergata University, Rome, I taly; and §National Veterinary Laboratory, Department of \\ Agriculture and Livestock, Boroko, Papua New Guinea
}

\begin{abstract}
We studied residents of remote villages and the capital (Port Moresby) of Papua New Guinea to determine the distribution of human herpesvirus-8 (HHV-8) infection. Our data suggest that HHV-8 has been endemic on the island for a long time and that the epidemiologic pattern of HHV-8 is more similar to that of herpes simplex virus-2 than hepatitis $\mathrm{C}$ virus.
\end{abstract}

The distribution of human herpesvirus-8 (HHV-8) infection and its main clinical consequence, Kaposi sarcoma (KS), appears to vary greatly by geographic area; however, its global distribution has not been determined (1). HHV-8-related viruses have been found not only in lower African and Asian simians and South American primates (2) but also in great apes, such as chimpanzees $(3,4)$. Although the precise time of divergence from related viruses of nonprimates is not known, evidence indicates that interspecies transmission to humans occurred on an evolutionary time scale of tens of thousands of years. HHV-8 seroprevalence studies of remote populations from different areas of the world may contribute to understanding the geographic origin and spread of the infection.

Paralleling the distribution of $\mathrm{KS}, \mathrm{HHV}-8$ rates are high in central Africa and low in the United States and Europe, except for Mediterranean countries, which have intermediate rates (1). Little information is available about the distribution of HHV-8 infection and $\mathrm{KS}$ in indigenous populations of Australasia. HHV-8 seroprevalence appears to be low in countries of Southeast Asia, such as Malaysia (5), where KS is considered very rare. In Papua New Guinea, little information is available about $\mathrm{KS}$, although cases have been reported among children, suggesting that it does occur, although it is probably relatively uncommon (6).

To verify whether HHV-8 infection is endemic in Papua New Guinea and to determine seroprevalence rates, we studied sera from Melanesian residents of remote villages in Western Province, Papua N ew Guinea. In Port Moresby, the capital, Melanesian residents were studied as a reference population group. Serologic tests for other viruses were also done to characterize the study population and explore modalities of transmission of HHV-8 infection by comparing the patterns of these infections with that of HHV-8.

\footnotetext{
Address for correspondence: Giovanni Rezza, Laboratory of Epidemiology and Biostatistics, I stituto Superiore di Sanità, Viale Regina Elena, 299, 00161, Rome, Italy; fax: 0039-06-49387210; e-mail: g.rezza@iss.it
}

\section{The Study}

The Melanesian study participants live in six remote villages (total population 524) in a flat, rural area called the Bensbach in southwestern Papua New Guinea. Participants from these villages were recruited for a study on trichinellosis, a parasitic infection recently reported in this area; at least $5 \mathrm{~mL}$ of venous blood had been collected from each participant in 1999, and these specimens were separated and treated as described elsewhere (7). Participants from Port Moresby were teachers and students at a local high school.

For serologic testing for antibodies to HHV-8 and other viruses, serum samples were stored at $-20^{\circ} \mathrm{C}$ in the laboratories of Tor Vergata University, Rome, Italy. As described $(8,9)$, antibodies to lytic and latent antigens of HHV-8 were detected by using two immunofluorescence assays based on the $B C B L-1$ cell line. Samples reactive at $>1: 20$ dilution were considered positive.

Antibodies to herpes simplex 2 (HSV-2) were detected by an immunoglobulin (lg) G-based type-specific enzyme-linked immunosorbent assay (ELISA; Gull Laboratories, Inc., Salt Lake City, UT). An ELISA was also used to detect antibodies to the Epstein-Barr virus (EBV) gp125 viral capsid antigen (Gull Laboratories, Inc.). Antibodies against hepatitis C virus (HCV) were detected by a third-generation enzyme immunoabsorbent assay (I nnotest HCV Ab III, I nnogenetics, Ghent, Belgium).

Seroprevalence ratios for each of the four viruses were calculated to assess differences stratified by age group, sex, and geographic area. These associations were evaluated by the chi-square test and the Cochran-Armitage test for trend. The viral correlates of HHV-8 infection were evaluated by estimating crude and adjusted prevalence ratios and their associated $p$-values by univariate and multivariate log-binomial linear regression analysis (GENMOD procedure in SAS, version 6.12). The relationship between antilytic and antilatent antibodies was assessed by calculating the proportion of antilatent positive persons by level of antilytic titer.

Sera from 150 participants, 56 from the villages and 94 from Port Moresby, were studied. Fifty-one (34\%) were female; the proportion of females was the same among village (19 [34\%] of 56) and urban (32 [34\%] of 94) residents. 


\section{Dispatches}

Median age was 22.5 years; residents of the remote area were older (median 35 years, range 15 to 85 ) than those recruited in the town (median 18 years, range 16 to 49 years).

Seroprevalence data for HHV-8 and the other viruses were stratified by age, sex, and area of residence (Table 1). HHV-8 and HSV-2 seroprevalence tended to increase with age. These increases, while different for each virus, were similar for urban and rural residents (for H HV-8, from $18.1 \%$ for those $<25$ years of age to $40.0 \%$ for those $>35$ in the city and from $18.2 \%$ to $41.4 \%$ in the villages; and for HSV-2, from $1.4 \%$ to $33.3 \%$ in the city and from $18.2 \%$ to $39.3 \%$ in the villages). Overall, age was significantly associated with infection with both HHV-8 (test for trend $\mathrm{p}=0.01$ ) and HSV-2 (test for trend $p=0.001$ ). No significant difference was observed between women and men, although HHV-8 prevalence was slightly higher in women. HHV-8 infection was more common in rural dwellers and HCV in the capital, but the differences were not statistically significant. Rural participants were four times more likely to be infected with HSV-2 than those in the city $(p=0.001)$, but this disparity was attributable to the differing age distribution of the two groups. No difference was seen in prevalence of EBV.

The analysis of serologic correlates of HHV-8 infection showed a significant association with HSV-2 infection (Table 2). However, after data were adjusted for age and other variables, the prevalence ratio of HHV-8 infection was no longer different from 1 for HSV-2-positive vs. -negative participants.

Of the $37 \mathrm{HHV}-8$ antilytic-positive participants, 16 had a titer of 1:20, 10 of 1:80, 9 of 1:160, and 2 of 1:320. Ten of these 37 also had antilatent antibodies. The proportion of antilatent positivity changed according to the antilytic titer: none of the 16 participants with an antilytic titer of 1:20 had antilatent antibodies, but $2(20 \%), 7(77.7 \%)$, and $1(50 \%)$ of those with antilytic titers of 1:80, 1:160, and 1:320, respec- tively, were also antilatent-positive. One antilytic-negative participant also had antilatent antibodies, with a titer of $1: 160$. Because the 16 residents with an antilytic titer of 1:20 did not have antilatent antibodies and could be considered false-positives, we repeated the analysis considering these participants as seronegative and obtained similar results (data not shown).

\section{Conclusions}

This study shows a relatively high prevalence of HHV-8 infection in Papua New Guinea; the prevalence does not appear to differ substantially between the capital and remote villages, suggesting that the infection has been endemic for a long time in this region and, as reported for other herpesvirus infections (10), can persist in small, isolated population groups. This similarity between remote rural communities and an urban center does not fully support the conclusions of a study on Amerindians of diverse tribes, which suggested that the limited genetic pool in isolated groups may permit more frequent transmission of a virus with a low prevalence than in heterogeneous populations (11).

Other viral infections, such as HSV-2, EBV, and HCV, were prevalent both in villages and the capital. In particular, HSV-2 was more common in remote villages, but the difference was largely explained by age. EBV prevalence was as high as expected on the basis of previous studies (12). The prevalence of HCV antibodies was higher in Port Moresby than in the villages; however, the difference was not statistically significant. A similar prevalence (4.1\%) was found in residents of villages in another part of Western Province (13).

The potential association between HHV-8 and HSV-2 was nonsignificant after the data were adjusted for age. Although seroprevalence of both infections tended to increase with age, the presence of HSV-2-negative and HHV-

Table 1. Seroprevalence of human herpesvirus-8 and other infections, stratified by geographic area, age, and sex

\begin{tabular}{|c|c|c|c|c|c|c|c|c|}
\hline \multirow{2}{*}{$\begin{array}{l}\text { Age } \\
\text { (years) }\end{array}$} & \multicolumn{2}{|c|}{$\mathrm{HHV}-8^{\mathrm{a}}$} & \multicolumn{2}{|c|}{ Epstein-Barr virus } & \multicolumn{2}{|c|}{ Hepatitis C virus } & \multicolumn{2}{|c|}{ Herpes simplex virus } \\
\hline & Urban & Rural & Urban & Rural & Urban & Rural & Urban & Rural \\
\hline$<25$ & $\begin{array}{c}13 / 72 \\
(18.1 \%)\end{array}$ & $\begin{array}{c}2 / 11 \\
(18.2 \%)\end{array}$ & $\begin{array}{c}61 / 66 \\
(92.0 \%)\end{array}$ & $\begin{array}{c}11 / 11 \\
(100.0 \%)\end{array}$ & $\begin{array}{c}7 / 71 \\
(9.9 \%)\end{array}$ & $0 / 11$ & $\begin{array}{c}1 / 72 \\
(1.4 \%)\end{array}$ & $\begin{array}{c}2 / 11 \\
(18.2 \%)\end{array}$ \\
\hline $25-35$ & $\begin{array}{c}3 / 12 \\
(25.0 \%)\end{array}$ & $\begin{array}{c}3 / 16 \\
(18.7 \%)\end{array}$ & $\begin{array}{c}10 / 12 \\
(83.3 \%)\end{array}$ & $\begin{array}{c}16 / 16 \\
(100.0 \%)\end{array}$ & $\begin{array}{c}1 / 12 \\
(8.3 \%)\end{array}$ & $\begin{array}{c}2 / 16 \\
(12.5 \%)\end{array}$ & $\begin{array}{c}3 / 12^{\mathrm{b}} \\
(25.0 \%)\end{array}$ & $\begin{array}{c}3 / 15 \\
(20.0 \%)\end{array}$ \\
\hline$>35$ & $\begin{array}{c}4 / 10 \\
(40.0 \%)\end{array}$ & $\begin{array}{c}12 / 29 \\
(41.4 \%)\end{array}$ & $\begin{array}{c}10 / 10 \\
(100.0 \%)\end{array}$ & $\begin{array}{c}28 / 29 \\
(96.6 \%)\end{array}$ & $\begin{array}{c}2 / 10 \\
(20.0 \%)\end{array}$ & $0 / 29$ & $\begin{array}{c}3 / 9^{b} \\
(33.3 \%)\end{array}$ & $\begin{array}{c}11 / 28 \\
(39.3 \%)\end{array}$ \\
\hline Male & $\begin{array}{c}14 / 62 \\
(22.6 \%)\end{array}$ & $\begin{array}{c}13 / 37 \\
(35.1 \%)\end{array}$ & $\begin{array}{c}56 / 61 \\
(91.8 \%)\end{array}$ & $\begin{array}{c}36 / 37 \\
(97.3 \%)\end{array}$ & $\begin{array}{c}6 / 61 \\
(9.8 \%)\end{array}$ & $\begin{array}{c}1 / 37 \\
(2.7 \%)\end{array}$ & $\begin{array}{c}5 / 61 \\
(8.2 \%)\end{array}$ & $\begin{array}{c}10 / 36 \\
(27.8 \%)\end{array}$ \\
\hline Female & $\begin{array}{c}6 / 32 \\
(18.7 \%)\end{array}$ & $\begin{array}{c}4 / 19 \\
(21.0 \%)\end{array}$ & $\begin{array}{c}30 / 32 \\
(93.7 \%)\end{array}$ & $\begin{array}{c}19 / 19 \\
(100.0 \%)\end{array}$ & $\begin{array}{c}4 / 32 \\
(12.5 \%)\end{array}$ & $\begin{array}{c}1 / 19 \\
(5.3 \%)\end{array}$ & $\begin{array}{c}2 / 32 \\
(6.2 \%)\end{array}$ & $\begin{array}{c}6 / 18 \\
(33.3 \%)\end{array}$ \\
\hline Total & $\begin{array}{c}20 / 94 \\
(21.3 \%)\end{array}$ & $\begin{array}{c}17 / 56 \\
(30.4 \%)\end{array}$ & $\begin{array}{c}86 / 93 \\
(92.5 \%)\end{array}$ & $\begin{array}{c}55 / 56 \\
(98.2 \%)\end{array}$ & $\begin{array}{c}10 / 93 \\
(10.7 \%)\end{array}$ & $\begin{array}{c}2 / 56 \\
(3.6 \%)\end{array}$ & $\begin{array}{c}7 / 93 \\
(7.5 \%)\end{array}$ & $\begin{array}{c}16 / 54^{c} \\
(29.6 \%)\end{array}$ \\
\hline
\end{tabular}

${ }^{\mathrm{a}} \mathrm{HHV}-8=$ human herpesvirus-8.

${ }^{b}$ Chi-square p-value $\varangle 0.05$, comparing age groups in rural and urban strata with reference group: $<25$ years.

${ }^{\mathrm{c} C h i-s q u a r e} \mathrm{p}$-value $<0.05$, comparing rural with urban. 


\section{Dispatches}

Table 2. Serologic correlates of human herpesvirus-8 infection, Papua New Guinea

\begin{tabular}{|c|c|c|c|c|c|}
\hline & $\mathrm{HHV}-8^{\mathrm{a}}$ & $\mathrm{PR}^{\mathrm{b}}$ & $\mathrm{p}$ & $A P R^{b}$ & $\mathrm{p}$ \\
\hline HCV- & $\begin{array}{c}35 / 137 \\
(25.5 \%)\end{array}$ & 1 & & 1 & \\
\hline $\mathrm{HCV}+$ & $\begin{array}{c}1 / 12 \\
(8.3 \%)\end{array}$ & .33 & 0.25 & 0.46 & 0.34 \\
\hline EBV- & $\begin{array}{c}1 / 8 \\
(12.5 \%)\end{array}$ & 1 & & 1 & \\
\hline EBV+ & $\begin{array}{c}35 / 141 \\
(24.8 \%)\end{array}$ & 1.98 & 0.47 & 1.71 & 0.54 \\
\hline HSV2- & $\begin{array}{l}25 / 124 \\
(20.2 \%)\end{array}$ & 1 & & 1 & \\
\hline $\begin{array}{l}\text { HSV2 } \\
+\end{array}$ & $\begin{array}{c}10 / 23 \\
(43.5 \%)\end{array}$ & 2.16 & 0.01 & 1.64 & 0.15 \\
\hline
\end{tabular}

${ }^{\mathrm{a}} \mathrm{HHV}-8$ = human herpesvirus-8; HCV = hepatitis C virus; EBV = Epstein Barr virus; $\mathrm{HSV} 2$ = herpes simplexvirus-2.

${ }^{\mathrm{b}}$ Prevalence ratio, crude and adjusted for age, sex, and urban residence.

8-positive young adults suggests that HHV-8 infection is not necessarily sexually transmitted. In particular, salivary spread, as for EBV, may not be ruled out, as suggested by studies conducted in isolated tribes of the New World, showing high prevalence rates in children $(11,14)$.

Some limitations and possible biases of our study should be mentioned. First, to what extent residents of isolated villages had contacts with others is difficult to quantify. Although government contact with the area was made early in the 20th century, infrastructure and services remain poor, making access difficult. There are no direct connections with this area, which during the rainy season can be reached only by canoe and then on foot, after a 1-hour flight from Port Moresby. To our knowledge, only one person had worked outside the area before retiring to his village of origin. Second, the differing age distribution between study participants recruited in urban and rural areas may represent a possible bias; however, the statistical analysis accounted for these differences. Finally, HHV-8 prevalence might have been overestimated if low antilytic titers were false-positive results; however, the specificity of our assay is supported by the high risk for $\mathrm{KS}$ among HIV-infected persons with low antilytic titers (9).

In conclusion, HHV-8 infection appears to be common in remote population groups of Papua N ew Guinea as well as in Port Moresby, suggesting that the infection has been endemic for a long time among the indigenous population of the country. The detection of a high prevalence of HHV-8 emphasizes the need for clinical monitoring of the study population. The identification of the main modes of transmission for HHV-8 and other infections may help in instituting public health measures to control the infection.

\section{Acknowledgment}

We thank A. Pisau for assistance in the field and G. Williamson for facilitating access to lines of communication. We also thank Drs. M. Mecgrath and D. Ganem for providing the BCBL-1 cell line.

This study was funded in part by the Programma Ricerche AIDS (Progetto Epidemiologia e Modelli Assistenziali, Azione Concertata HHV-8), Istituto Superiore di Sanità. Funds for airfares in Papua New Guinea were supplied by the North Australia Quarantine Strategy.

Dr. Rezza is a medical epidemiologist and director of the AIDS and STD Unit, Laboratory of Epidemiology and Biostatistics, Istituto Superiore di Sanità (Italian National Institute of Health). His research focuses on HIV, HHV-8, and other potentially oncogenic sexually transmitted viruses.

\section{References}

1. Antman K, Chang Y. Kaposi's sarcoma. N Engl J Med 2000;342: 1027-38.

2. Sinkovics J G, Horvath J C. Kaposi's sarcoma: breeding ground of herpesviridae-A tour de force over viral evolution. Int J Oncol 1999;14:615-46.

3. Lacoste V, Mauclère $P$, Dubreuil G, Lewis J, Georges-Courbot MC, Gessain A. KSHV-like herpesviruses in chimps and gorilIas. Nature 2000;407:151-2.

4. Greensill J, Sheldon J A, Murthy KK, Bessonette J S, Beer BE, Schulz TF. A chimpanzee rhadinovirus sequence related to Kaposi's sarcoma-associated herpesvirus/human herpesvirus 8: increased detection after HIV-1 infection in the absence of disease. AIDS 2000;14:129-35.

5. Ablashi D, Chatlynne L, Cooper H, Thomas D, Hadav M, Norhanom AW, et al. Seroprevalence of human herpesvirus-8 (HHV-8) in countries of Southeast Asia compared to USA, the Caribbean and Africa. Br J Cancer 1999;81:893-7.

6. Sengupta SK, Edwards K, Blair A, Hamilton DR, Niblet J S. Childhood Kaposi's sarcoma in Papua N ew Guinea. Aust Paediatr J 1986;22:301-4.

7. Pozio E, Owen IL, La Rosa G, Sacchi L, Rossi P, Corona S. Trichinel la papuaen.sp. (Nematoda), a new non-encapsulated species from domestic and sylvatic swine of Papua New Guinea. Int J Parasitol 1999;29:1825-39.

8. Andreoni M, El-Sawaf G, Rezza G, Ensoli B, Nicastri E, Ventura $L$, et al. High seroprevalence of antibodies to human herpesvirus-8 in Egyptian children: evidence of non-sexual transmission. J Natl Cancer Inst 1999;91:465-9.

9. Rezza G, Andreoni M, Dorrucci M, Pezzotti P, Monini P, Zerboni $R$, et al. Human herpesvirus-8 seropositivity and risk of Kaposi's sarcoma and other acquired immunodeficiency syndrome-related diseases. J Natl Cancer Inst 1999;91:1468-74.

10. Black FL, Hierholzer WJ, de Pinheiro F, Evans AS, Woodall J P, Opton EM, et al. Evidence for persistence of infectious agents in isolated human populations. Am J Epidemiol 1974;100:230 50.

11. Biggar RJ, Whitby D, Marshall V, Linhares AC, Black F. Human herpesvirus 8 in Brazilian Amerindians: a hyperendemic population with a new subtype. J Infect Dis 2000;181:1562-8.

12. Lang DJ, Garruto RM, Gajdusek DC. Early acquisition of Cytomegalovirus and Epstein-Barr virus antibody in several isolated Melanesian populations. Am J Epidemiol 1977;105:480-7.

13. Yamaguchi $K$, Inaoka $T$, Ohtsuka R, Akimuchi $T$, Hongo $T$, Kawabe T, et al. HTLV-I, HIV-1, and hepatitis B and C viruses in Western Province, Papua New Guinea: a serological survey. J pn J Cancer Res 1993;84:715-9.

14. Plancoulaine $S$, Abel $L$, van Beveren $M$,Tregouet DA, J oubert $M$, Tortevoye $P$, et al. Human herpesvirus 8 transmission from mother to child and between siblings in an endemic population. Lancet 2000;356:1062-5. 